\title{
THE USE OF REMOTE SENSING TECHNIQUES IN ASSESSING THE DISTRIBUTION TRENDS OF COMMIPHORA MYRRHA IN WAJIR COUNTY, KENYA
}

\author{
Luvanda A. ${ }^{1, *}$, Wanjiru G. ${ }^{2}$ and Makatiani E. ${ }^{2}$ \\ ${ }^{1}$ Kenya Forestry Research Institute, Dryalnd Eco-region Research Programme, Kitui, Kenya. ${ }^{2}$ Kenya \\ Forestry Research Institute, Nairobi. Corresponding author: luvandaa@gmail.com
}

\begin{abstract}
.
A study was conducted to establish the current trend in distribution of Commiphora myrrha in its natural stands in Wajir County. Data was collected through observation, interviews and questionnaires, photographs (remote sensing images) using a Global Positioning System (GPS) to to mark the plant's hot spots and locate the tree stand coordinates. A supervised classification of Land Sat images acquired in 2003, 2009 and 2011 was undetaken. The results show that $C$. myrrha covers an average area of $61,620.23 \mathrm{Ha}$. The area under $C$. myrrha had declined between 2009 and 2011 and this could be attributed to human and environmental factors. It is therefore recommended that sustainable management and conservation strategies be adopted to ensure imprived tree cover.
\end{abstract}

\section{ОПЫТ ИСПОЛЬЗОВАНИЯ БЕСПИЛОТНЫХ ЛЕТАТЕЛЬНЫХ АППАРАТОВ В БИОГЕОГРАФИЧЕСКИХ ИССЛЕДОВАНИЯХ НА ТЕРРИТОРИИ ЗАПОВЕДНИКА «БЕЛОГОРЬЕ»}

\author{
Н.А. Алексеенко*, А.А. Медведев**, И.А. Карпенко*** \\ *ФГБУ ГПЗ «Белогорье», Россия, Белгородская область \\ **ИГРАН, Россия, Москва \\ ***МГУ имени М.В.Ломоносова, Россия, Москва
}

\section{THE EXPERIENCE OF UAV'S USE FOR BIOGEOGRAPHICAL RESEARCH IN «BELOGORIE» NATURAL RESERVE}

\author{
N.A. Alekseenko**, A.A. Medvedev*, I.A. Karpenko.** \\ *Institute og geography RAS, Russia, Moscow \\ **MSU by M.V.Lomonosov, Russia, Moscow
}

\begin{abstract}
The article describes the experience of field biogeographic studies in the natural reserve "Belogorie" with the use of UAV in autumn, winter and spring seasons. Particular emphasis is placed on the zoogeographical problems.

Also, the authors analyze the international experience of UAV's use in geographical research and give suggestions for further development of biogeographic studies using thermal, multispectral cameras and gas analyzers.
\end{abstract}

В настоящее время беспилотные летательные аппараты (БПЛА) начали твердо занимать свою нишу в различных сферах деятельности человека. Успешное использование БПЛА в военных областях способствовало их широкому применению в гражданских целях. Они находят свое применение в градостроительстве, экологическом мониторинге, геологоразведке, при дистанционном контроле нефтегазопроводов и др.

Многолетний опыт использования данных дистанционного зондирования Земли позволил БПЛА быстро найти применение в географических исследованиях, в т.ч. в биогеографии. Особенно важны такие исследования при изучении особо охраняемых природных территорий, основной задачей которых, является сохранение биологического и ландшафтного разнообразия уникальных природных экосистем. Выполнение этой задачи сопряжено с некоторыми проблемами:

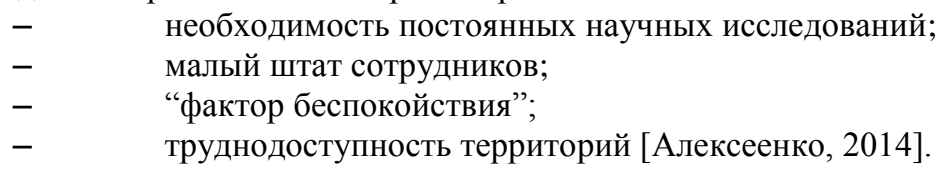

